\title{
FUNGI AND SOIL MACROFAUNA COMMUNITY IN REVEGETATED POST-FIRE PEATLAND IN CENTRAL KALIMANTAN
}

\author{
Safinah S. Hakim, Wawan Halwany and Dony Rachmanadi \\ Banjarbaru Environment and Forestry Research Instiitute \\ Jl. Ahmad Yani Km 28,7 Banjarbaru, South Kalimantan, Indonesia
}

Received: 27 August 2018, Revised: 17 September 2019, Accepted: 6 October 2019

FUNGI AND MACROFAUNA COMMUNITY IN POST-FIRE PEATLAND IN CENTRAL KALIMANTAN. Peat soil with its unique physical and chemical character is host to various microbe and fauna. In the peat, the existence of microbe and macrofauna influenced by several environmental parameters. This paper investigates the fungi and macrofauna community in the post fire degraded peat swamp soil with emphasize on two points: the abundance of soil fungi and soil macrofauna and to describe the environmental parameters (e.g. understory and chemical properties) on the existence of fungi and macrofauna community. Soil dilution and pitfall trap methods were used to collect soil fungi and macrofauna in four different plots based on the revegetation time which are: no revegetation (A), 12 months after revegetation (revegetated in December 2016) (B), 21 months after revegetation (revegetated in April 2016) (C), and 24 months after revegetation (revegetated in December 2015) (D). Result showed that abundance of soil fungi obtained during this study is $4 \times 105$ to $11 \times 105 \mathrm{cfu} / \mathrm{ml}$. While the macrofauna abundance is $353-1038 \mathrm{ind} / \mathrm{m}^{2}$. Soil fungi and macrofauna community in peatland affected by understory cover which was related with revegetation activity. There is a trend of increasing the abundance of soil fungi and macrofauna on the post-fire peatland along with the increase of the percentage of understory cover.

Keywords: Abundance, forest fire, macrofauna, microbe, peat

KOMUNITAS JAMUR DAN MAKROFAUNA PADA LAHAN GAMBUT BEKAS TERBAKAR DI KALIMANTAN TENGAH. Tanah gambut yang memiliki karakter fisika dan kimia yang unik merupakan babitat bagi berbagai macam mikroba dan fauna. Di tanah gambut, adanya mikroba dan makrofauna dipengarubi oleh beberapa parameter lingkungan. Penelitian ini dilakukan dengan tujuan untuk mengetabui informasi tentang komunitas jamur dan makrofauna di lahan gambut bekas terbakar dengan berfokus pada dua hal yakni: kelimpahan jamur tanah dan makrofanna tanah dan hubungan parameter lingkungan dengan komunitas mikroba yang ada. Pengenceran tanah dan metode perangkap sumuran digunakan untu mendapatkan sampel jamur dan makrofauna pada plot yang telah ditentukan yakni: lahan gambut bekas terbakar yang belum di revegatasi (A), lahan gambut bekas terbakar yang sudah direvegetasi 12 bulan (B), lahan gambut bekas terbakar yang sudah di revegetasi 21 bulan (C), dan lahan gambut bekas terbakar yang sudah direvegetasi 24 bulan (D). Kelimpaban jamur tanah yang didapatkan selama penelitian ini adalab 4×105 cfu/ml bingga 11×105 cful $m l$ dan kelimpahan makrofauna adalah 353-1038 individu/ $\mathrm{m}^{2}$. Kelimpahan jamur dan makrofauna dipengarubi oleh persentase penutupan tumbuhan bawah yang berbubungan dengan aktivitas re-vegetasi. Semakin tinggi persentase penutupan tumbuban bawah, maka semakin tinggi pula kelimpahan jamur dan makrofauna tanah.

Kata kunci: Kelimpahan, kebakaran hutan, makrofauna, mikroba, gambut

\footnotetext{
${ }^{*}$ Corresponding author: safinah.hakim@gmail.com
} 


\section{INTRODUCTION}

Soil fungi and macrofauna play a big role in soil ecosystem, such as influencing soil property, hydrology, aeration and gaseous composition which important in soil productivity and plant that grow above it (Brussaard, 1997). Most of named and studied fungi ( $\pm 80,000$ species $)$ are mostly grown in soil habitat (Bridge $\&$ Spooner, 2001), including in peat soil. Peat soil with its unique physical and chemical character is host to various microbe including bacteria, saprobe, endophyte fungi (Hakim, Yuwati, \& Nurulita, 2017), Mycorrhizal Arbuscular fungi (Tawaraya et al., 2003), Ectomycorrhiza (Turjaman et al., 2005). Microbe in peatland has important roles in the decomposition of organic matter (M.N. Thormann \& Rice, 2007; Thormann, Rice, \& Beilman, 2007; Bridge \& Spooner, 2001). As well as microbe, macrofauna in peatland also has an important roles in soil ecosystem such as influences soil turnover, mineralization, soil physic and chemistry, soil nutrient content, and water availability (Bottinelli et al., 2015; Lal, 1988).

Tumbang Nusa Research Forest (KHDTK Tumbang Nusa) experienced several forest fire in 1997, 2003, 2006 and 2015. Repeatedly forest fire in Tumbang Nusa, Central Kalimantan lead by several caused, i.e extreme dry season (El Nino), land clearing, land conflict, and lack of law enforcement. Durinf the last forest fire incident in 2015, KHDTK Tumbang nusa has lost approximately $2,700 \mathrm{Ha}$ or $54 \%$ to its total area. It is estimated about $500 \mathrm{~m}^{3}$ biomass/ ha were burned that caused great loss of biodiversity, research data and plots (Santosa \& Qirom, 2016). Several activities were carried out in KHDTK Tumbang Nusa to restore the ecosystem including microorganism, macrofauna, wildlife, and also the vegetation. Several revegetation activities were done to restore degraded post-fire peat land in Tumbang Nusa, ie. in December 2015, in April 2016 and December 2016.

Forest fire affected many aspects on the ecosystem, such as economic, social, and ecology including loss of plant biodiversity, soil microbes, and also soil macrofauna (Meador, Springer, Huffman, Bowker, \& Crouse, 2017; Koster et al., 2015; Wang, Wang, Wang, Hu, \& Luo, 2015). Fire affected microorganism in the organic horizons and in the top 1-2 cm of soil layer, the location where the burning and heating effect could reach moderate to critical severity. Fire will change soil environment that affects the function of fungi soil and macrofauna community (Meador et al., 2017; Gongalsky \& Persson, 2013a; Neary, Klopatek, Debano, \& Folliott, 1999).

In general habitat, revegetation is one of the solution to alter ecosystem after fire. Revegetation will give the reciprocal effect to the soil that directly support the plant growth. The success of revegetation activities can be seen from several parameters such as plant growth and also the re-existence of living creature including microbe (An, Cheng, Huang, \& Liu, 2013; An, Huang, \& Zheng, 2009; Rolda, 2005) and also macrofauna (Gupta, Gorai, \& Sighn, 2007; Ruiz-jaen \& Aide, 2005). However, the baseline information about the fungal and macrofauna community in revegetated post-fire peat land is still limited. Therefore, this study would like to obtain the information about fungi and macrofauna in the post-fire degraded peat swamp soil after revegetation activity with emphasize on two points which are (i) abundance of soil fungi and soil macrofauna, and (ii) to describe the environmental parameters (e.g. understory cover and chemical properties) on the existence of fungi and macrofauna community.

\section{MATERIAL AND METHOD}

\section{A. Study Site}

The study was carried out in September to December 2017 in Tumbang Nusa Research Forest (KHDTK Tumbang Nusa), Tumbang Nusa village, Pulang Pisau, Central Kalimantan (02'18'34'S and $114^{\circ} 02^{\prime}$ '48'E) and in Microbiology Laboratory of Banjarbaru Environment and Forestry Research and 
Development Institute, Banjarbaru, South Kalimantan. KHDTK Tumbang Nusa covered with peatland with elevated area about $0-5 \mathrm{~m}$ above sea level. Annual rainfall is about 2000$3000 \mathrm{~mm} /$ year with minimum temperature is $21^{\circ} \mathrm{C}$ and maximum temperature is $36^{\circ} \mathrm{C}$. KHDTK Tumbang Nusa dominated by hemic peat with low bulk density (0.04-0.16) with soil acidity $(\mathrm{pH})$ less than 4 . Sampling points were located in four different plots based on the revegetation time which are: no revegetation (A), 12 months after revegetation (revegetated in December 2016) (B), 21 months after revegetation (revegetated in April 2016) (C), and 24 months after revegetation (revegetated in December 2015). Observation were done to the fungi and macrofauna community in several parameters which are species, abundance, understory cover, and soil chemical properties.

\section{B. Method}

1. Soil Sample Collection and Fungal Isolation

Soil sample from $0-30 \mathrm{~cm}$ soil surface were collected from four sampling point at post-burn peat land. In each point sampling location, we took one sample about $500 \mathrm{gr}$ soil. Soil dilution technique to measure fungal abundance was done according to Kruger, Sharma, and Ajit (2009). Ten gram's of soil sample was mixed with $90 \mathrm{ml}$ of sterile distilled water (10-1 dilution), then shook for 30 minutes (100 rpm). This initial dilution was done to 10-4 dilution. Fungal abundance determined with following formula:

$$
T P C=\Sigma \text { colony } \times \frac{1}{\text { suspension }} \times \frac{1}{f p}
$$

Where:

$\mathrm{TPC}=$ Total Plate Count; $\mathrm{fp}=$ total dilution factor.

Fungal morphospecies was obtained by incubated fungi which grow in Potato Dextrose Agar and isolated until we obtain single culture fungi. Fungal morphospecies were determined according to cultural characteristic: colony colour, texture, habit, and growth rate on petri dish containing PDA.

\section{Soil Macrofauna Observation}

Soil macrofauna was observed using pitfall trap method which refers to Suhardjono, Deharveng, and Bedos (2012) and Maftuah, Alwi, and Willis (2005) One small plastic container $(\mathrm{d}=7 \mathrm{~cm}, \mathrm{~h}=10 \mathrm{~cm})$ filled with insect preservatives $(70 \%$ alcohol) was placed in the soil targeted plot. In addition, the plastic container rims were placed at the same level with soil surfaces. To protect the container from rain, a small cover was made above the trap. Samples were taken $2 \times 24$ hours after the trap was installed. Macrofauna that trapped inside the plastic container were put into vials bottle to identify. Identifications were conducted according to Borror, Triplehorn, and Johnson (1992). Furthermore, Shannon and Wiener index was used to calculate the diversity of soil macrofauna (Krebs, 1978).

\section{Understory Cover}

Understory cover data were collected by using $1 \times 1 \mathrm{~m}$ plot which photographed from above ground using digital camera. Can-eye software was used to determine the land cover percentage that dominated by understory plant. In each sampling point, the analysis was performed in triplicate.

\section{Soil Analysis}

Soil sample from the upper soil horizon $(0-30 \mathrm{~cm})$ of each point sampling were taken to soil laboratory of Indonesian Swampland Agriculture Research Institute, Banjarbaru, South Kalimantan. Chemical and physical parameter were measured which are $\mathrm{pH}$ $\mathrm{H}_{2} \mathrm{O}$, Electrical Conductivity $(\mathrm{EC})(\mathrm{mS} / \mathrm{cm})$, $\mathrm{N}(\%), \quad \mathrm{Kdd}(\mathrm{cmol}(+) / \mathrm{kg}), \mathrm{CEC}(\mathrm{cmol}(+) /$ $\mathrm{kg})$, P Bray1(ppm P), P potential (mg/100 gr), $\mathrm{K}$ potential (mg/100 gr), ash (\%) and water content $(\%)$.

\section{RESULT AND DISCUSSION}

Peat soils with all its limitations: acidic soil, low nutrient levels, and also post-burn soil are habitats for various fungi, bacteria as well as macrofauna. This is proven by the 


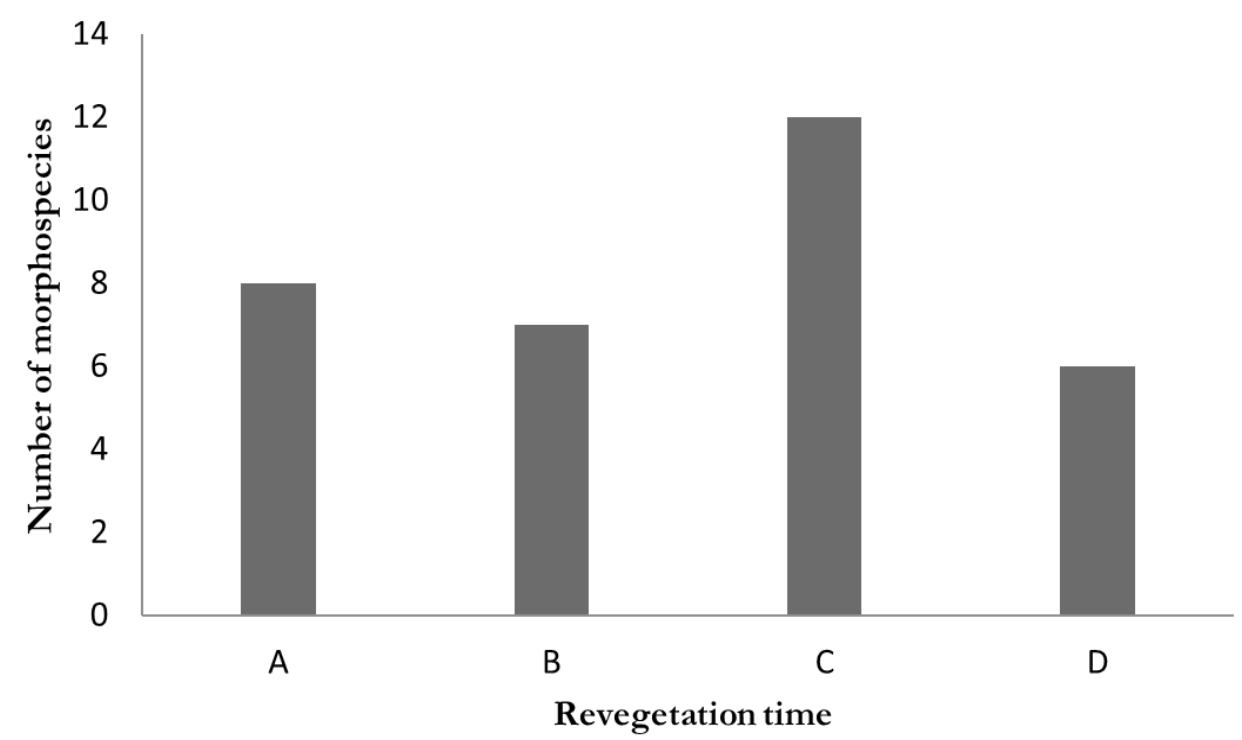

Remarks: (A), 12 months after revegetation (B), 21 months after revegetation post-fire peat-land revegetated in April 2016 (C), and 24 months after revegetation (D)

Figure 1. Number of fungal morphospecies isolated from four post-fire peatland plots: no revegetation

Table 1. Number of fungal colonies, macrofauna genus, diversity index and vegetation cover in four sampling points

\begin{tabular}{ccccc}
\hline Revegetation time & $\begin{array}{c}\text { Number of fungal } \\
\text { colonies }(\mathrm{cfu} / \mathrm{ml})\end{array}$ & $\begin{array}{c}\text { Number of } \\
\text { macrofauna genus }\end{array}$ & $\begin{array}{c}\text { Macrofauna } \\
\text { diversity index }\end{array}$ & $\begin{array}{c}\text { Understory cover } \\
(\%)\end{array}$ \\
\hline A (no revegetation) & $5 \times 10^{5}$ & 7 & 1.29 & 6.83 \\
B (12 months) & $4 \times 10^{5}$ & 6 & 1.38 & 12.61 \\
C (21 months) & $10 \times 10^{5}$ & 8 & 0.83 & 14.32 \\
D (24 months) & $11 \times 10^{5}$ & 10 & 1.55 & 31.93 \\
\hline
\end{tabular}

successfull isolation of fungi and the discovery of macrofauna in our sampling plot, which are burnt peat soil. The result obtained in our study indicate that fungal abundance in the area with 24 months old revegetation plants has the highest abundance compare to others location (Table 1). In the location that revegetated in April 2016 (21 months old revegetation plants), the number of fungi morphospecies was found at most (12), with the lowest number of morphospecies found in site d (6) (Figure 1). The high amount of colony or fungal abundance not followed by the number of morphospecies.

In general, post degraded peatland or cutover peatland tend to have lower microbial biomass due to affected by many environmental factors such as moisture content, temperature (Trinder,
Johnson, \& Artz, 2008). In peat soil, soil fungal abundance categorized as low level, about $1 / 3$ to $1 / 30$ compare to non-peat land soil such as evergreen forest and cultivated soil (Yabuki, Duncan, \& Okuda, 2013). Result revealed that the abundance of fungi increases along the increament of understory cover. Denser cover reduces temperature and increases relative humidity that provide better habitat for fungal growth (Shuhada, Salim, Nobilly, Zubaid, \& Azhar, 2017). In addition, the abundance of fungi did not follow by number of morphospecies. However, in comparison with those of peatland in other areas, such as in Japan, fungal abundance in tropical peatland in Central Kalimantan tends to have higher abundance ( $5 \times 105$ to $11 \times 105)$, while in peat 
soil japan, fungal abundance was $3.3 \times 103$ and $3.0 \times 103$. The higher diversity of vegetation in tropical peat, which has role as fungal host, compared to peat in temperate region, which has lower vegetation diversity, could affect the fungal abundance (Arnold, 2007).

No fungal identification activity were done during this research, but according to Thormann and Rice (2007), there were some common fungi documented in Canada peat soil are Basidiomycetes, Zygomycetes, Chytridiomycetes. In addition, the most common genus found in Canada peat soil are Penicillum, Galerina, and Mortiella species. There is a possibility that the abundance of fungi in peatland is higher than the result that we obtained during this study. According to Kirk et al. (2004), fast growth rate of microbes and microbes that produce a huge number of spore is causing difficulties in the observation, and also could lead growth inhibition and colony spreading. In addition, only culturable fungi can be grown with agar media. These facts supporting the theory that only $17 \%$ fungi can be cultured (Bridge \& Spooner, 2001).

Instead of having a high number of morphospecies, Plot D also known to have highest fungal abundance, macrofauna abundance, macrofauna diversity index and also highest vegetation cover (Table 1 and 2). The result also showed that the abundance of microbe and microfauna tend to increased along with the increment of understory cover percentage.

There was a unique pattern in macrofauna abundance found during this research. In the non-revegetation area, the number of macrofauna is higher compared to the revegetation plot. However, in the revegetation area, there are improvement of macrofauna availability along with the increament of understory cover. Furthermore, Orthoptera dan Hymenoptera (Table 2) were two dominant insects order obtained by the pitfall trap of macrofauna in this study. Analysis showed no differences of soil chemical composition in four different samples. However, the water content tends to increase along the duration of revegetation activity.

Effect of fire on macrofauna activities depends on several factor which are fire intensity and the macrofauna species itself (Coyle et al., 2017). The fire will impact the diversity of macrofauna. According to Istomo and Pradiastoro (2011) there is three categories of diversity index: low $(<2)$, moderate $(2-3)$ and high $(>3)$. Previous study in peat area shown that macrofauna diversity index in peat area is in low to moderate category. In addition, Halwany, Andriany, and Manaon (2014) in his research mentioned that the diversity index in several peat areas is categorized in low to moderate (0.33-1.33). While, in this study, all of our sampling points have diversity index about $0.38-0.55$, which categorized as low biodiversity compare to others plot near to our sampling points. As well as the fungal community, the macrofauna community also has the same trend as microbe community that has higher abundance in the area which has higher understory cover. However, there is a unique pattern in macrofauna community which

Table 2. Soil macrofauna abundance in four sampling points

\begin{tabular}{|c|c|c|c|c|c|c|c|c|c|c|c|c|c|c|c|c|}
\hline \multirow[t]{2}{*}{ Order } & \multicolumn{4}{|c|}{ A (no revegetation) } & \multicolumn{4}{|c|}{ B (12 months) } & \multicolumn{4}{|c|}{$\mathrm{C}$ (21 months) } & \multicolumn{4}{|c|}{$\mathrm{D}$ (24 months) } \\
\hline & $\mathrm{j}$ & $\sum \mathrm{i}$ & $\mathrm{F}$ & RD & $\mathrm{j}$ & $\sum \mathrm{i}$ & $\mathrm{F}$ & $\mathrm{RD}$ & $\mathrm{j}$ & $\sum \mathrm{i}$ & $\mathrm{F}$ & RD & $\mathrm{j}$ & $\sum \mathrm{i}$ & $\mathrm{F}$ & $\mathrm{RD}$ \\
\hline Orthoptera & 1 & 354 & 90 & 56 & 1 & 196 & 30 & 56 & 1 & 496 & 85 & 81 & 1 & 527 & 85 & 51 \\
\hline Hymenoptera & 4 & 212 & 65 & 33 & 2 & 102 & 50 & 29 & 4 & 102 & 45 & 17 & 3 & 307 & 60 & 30 \\
\hline Coleoptera & 1 & 15 & 10 & 3 & 1 & 39 & 15 & 11 & 2 & 16 & 5 & 1 & 4 & 173 & 35 & 16 \\
\hline Araneae & 1 & 6 & 20 & 8 & 0 & 0 & 0 & 0 & 1 & 8 & 5 & 1 & 1 & 31 & 15 & 3 \\
\hline Diptera & 0 & 47 & 0 & 0 & 1 & 16 & 10 & 4 & 0 & 0 & 0 & 0 & 0 & 0 & 0 & 0 \\
\hline Total & 7 & 634 & & & 5 & 353 & & & 8 & 622 & & & 9 & 1038 & & \\
\hline
\end{tabular}

Remarks: j : species number; $\sum \mathrm{I}$ : individual number $/ \mathrm{m}^{2}$; F: frequency $(\%)$; RD: relative density (\%) 
different compare to microbe community. In the non-revegetation area, macrofauna abundance is higher compare to the revegetation area. Less predator in open area (non-revegetated) caused by higher colony of some macrofauna compare to revegetated area (Gongalsky \& Persson, 2013a). This result supporting theory from Carpenter et al., (2012) that macrofauna is less diverse in the area with dense canopy cover and less diverse in open area. Therefore, it could be assumed that canopy cover affected the diversity of macrofauna.

Ant, which is classified in the family of Formicidae, is the most common macrofauna found in this study. According to Carpenter et al. (2012), Formicidae is commonly found in open area of forest. For example, Wawan Halwany, (2011) and Harun (2011) also found many Formicidae species in agroforestry area in Kelampangan, Tumbang Nusa which are peat area. Furthermore, Halwany et al. (2014) also found many of formicidae in peat area central Kalimantan and followed by other common insect families which are Glossoscolicidae, Formicidae, and Chillapoda. In the soil, ant play important roles in soil amandement. According to Frouz and Jilkova (2008) ants (formicidae) could mediated chemical change, increasing nutrient content in the soil by its nest occurrence in soil. In addition, ants also affect the soil physical condition and also increasing microbial activities.

The existence of Formicidae and the other insect in post-fire habitat occur by these two assumptions: (a) macrofauna that migrate from unburnt area into post-fire, (b) macrofauna that survive in the deep soil layer or in the unburnt location (Gongalsky \& Persson, 2013b). Burning affected the soil macrofauna abundance and biomass but not so significantly affect the species richness (Gongalsky et al., 2012). In contrast, Malmstrom et al. (2009) in their research mentioned that fire decreased soil macrofauna species richness. In addition, Malmstrom, Persson, Ahlstro, and Malmstro (2009) stated that forest fire greatly affect to several insect order of soil macrofauna, including order that easy and have good ability to migrate and disperse such as Diptera, Coleptera and Aranea. Five years after fire incident, these species still absent and difficult to find in the post-burning area.

Many theories mention that environmental factor plays an important role with bacteria, fungi, and soil macrofauna abundance in several habitats. Biological community in the soil will respond to the habitat disturbance or degradation (Mandal \& Sathyaseelan, 2012). In the soil, the fungal community and distribution have positive correlation with $\mathrm{pH}$, soil temperature and humidity. While, altitude and soil moisture content have negative correlation with fungal distribution in the soil (Devi, Khaund, Nongkhlaw, \& Joshi, 2012). Based on the analysis result (Table 2), plot D that have the highest percentage of land cover show highest fungal abundance and macrofauna. It is assumed, vegetation cover affected soil humidity and soil temperature that support the life of microbe and macrofauna.

On the contrary with the theories, soil analysis result (Table 3) on four sampling location showed no differences in several parameters. However, there are increasing of water content percentage along with the age of the revegetation tree. Based on these results, it can be assumed that 24 month after revegetation activity have not change or alter the chemical composition of the peat soil It is assumed that during 24 months, there are slow change in peat chemical properties. This result linear with the study of Too, Keller, Sickel, Lee, \& Yule (2018) that mentioned that environmental variables ( $\mathrm{pH}$, nutrient availability, and $\mathrm{C} / \mathrm{N}$ ratio) does not significantly impact in peat with different vegetation due to the waterlogging and regular flooding that lead the nutrients redistributed to forest soil.

No understory coveridentification were done during this research but we assumed the litter of understory plant could affect the microbes and macrofauna community. According to Trinder et al. (2008), fungal community in peat was dominantly determined by litter type because 
Table 3. Chemical content of soil in four sampling points

\begin{tabular}{lrrrr}
\hline \multicolumn{1}{c}{ Chemical properties } & $\begin{array}{c}\mathrm{A} \\
\text { (no revegetation) }\end{array}$ & $\begin{array}{c}\mathrm{B} \\
(12 \text { months) }\end{array}$ & $\begin{array}{c}\mathrm{C} \\
(21 \text { months) }\end{array}$ & $\begin{array}{c}\mathrm{D} \\
(24 \text { months })\end{array}$ \\
\hline $\mathrm{pH} \mathrm{H} \mathrm{H}_{2} \mathrm{O}$ & $3.64 \pm 0.27^{\mathrm{a}}$ & $3.24 \pm 0.12^{\mathrm{a}}$ & $3.41 \pm 0.11^{\mathrm{a}}$ & $3.65 \pm 0.26^{\mathrm{a}}$ \\
$\mathrm{EC}(\mathrm{ms} / \mathrm{cm})$ & $0.12 \pm 0.07^{\mathrm{a}}$ & $0.22 \pm 0.12^{\mathrm{a}}$ & $0.14 \pm 0.02^{\mathrm{a}}$ & $0.12 \pm 0.07^{\mathrm{a}}$ \\
$\mathrm{N}$ total $(\%)$ & $0.81 \pm 0.19^{\mathrm{a}}$ & $0.84 \pm 0.09^{\mathrm{a}}$ & $0.77 \pm 0.11^{\mathrm{a}}$ & $0.81 \pm 0.13^{\mathrm{a}}$ \\
$\mathrm{K}-\mathrm{exc}(\mathrm{cmol}(+) / \mathrm{kg})$ & $0.57 \pm 0.23^{\mathrm{a}}$ & $0.90 \pm 0.26^{\mathrm{a}}$ & $0.79 \pm 0.29^{\mathrm{a}}$ & $0.73 \pm 0.19^{\mathrm{a}}$ \\
$\mathrm{CEC}(\mathrm{cmol}(+) / \mathrm{kg})$ & $182.28 \pm 43.96^{\mathrm{a}}$ & $182.30 \pm 5.27^{\mathrm{a}}$ & $172.01 \pm 11.13^{\mathrm{a}}$ & $189.67 \pm 38.37^{\mathrm{a}}$ \\
$\mathrm{P} \mathrm{Bray}(\mathrm{ppm} \mathrm{P)}$ & $16.88 \pm 14.91^{\mathrm{a}}$ & $24.27 \pm 13.32^{\mathrm{a}}$ & $12.84 \pm 1.91^{\mathrm{a}}$ & $19.64 \pm 9.35^{\mathrm{a}}$ \\
$\mathrm{P}$ potential $(\mathrm{mg} / 100 \mathrm{~g})$ & $2.18 \pm 0.53^{\mathrm{a}}$ & $3.5915 \pm 1.38^{\mathrm{a}}$ & $2.09075 \pm 0.41^{\mathrm{a}}$ & $3.27 \pm 1.06^{\mathrm{a}}$ \\
$\mathrm{K}$ potential $(\mathrm{mg} / 100 \mathrm{~g})$ & $19.19 \pm 8.38^{\mathrm{a}}$ & $30.97 \pm 10.61^{\mathrm{a}}$ & $22.25 \pm 5.19^{\mathrm{a}}$ & $23.79 \pm 6.03^{\mathrm{a}}$ \\
Ash content $(\%)$ & $6.42 \pm 2.89^{\mathrm{a}}$ & $9.58 \pm 4.56^{\mathrm{a}}$ & $12.84 \pm 4.56^{\mathrm{a}}$ & $10.14 \pm 5.71^{\mathrm{a}}$ \\
Water content $(\%)$ & $28.83 \pm 4.98^{\mathrm{a}}$ & $41.26 \pm 10.86^{\mathrm{a}}$ & $58.71 \pm 11.52^{\mathrm{a}}$ & $55.11 \pm 27.35^{\mathrm{a}}$ \\
\hline
\end{tabular}

Remarks: *Means with different letter show significant differences at $95 \%$ of confidence by the Tukey's test

litter type changes the turnover stats of $\mathrm{C}, \mathrm{N}$, and $\mathrm{P}$ in the soil.

In general, revegetation activities are playing an important role in restoring degraded peat land. In areas with high vegetation cover, moisture will increase and the environment conditions will support the growth of culturable soil fungi and macrofauna. The existence of these microorganisms and macrofauna ultimately gives advantages to the plant and the whole ecosystem through plant-insect and microbes interaction. This study result showed that revegetation activity playing an important role in restoring degraded peat land.revegetation will increase moisture and humidity and alter micro-climate that support the growth of soil fungi and macrofauna. the existence of these microorganisms and macrofauna ultimately gives the plant and the whole ecosystem through the insect plant and microbes interaction.

The results of the study certainly illustrate that in revegetation activities, plant growth parameters are not the only indicator of success, but biological communities such as microbes and macrofauna are also important indicators and play a role in determining the success of revegetation. Hence, technology inputs are needed to succeed of revegetation activities such as by utilizing the active charcoal
(Gusmailina, 2010), utilizing soil amandment (Dariah, Sutono, Nurida, \& Hartatik, 2015), application of soil microbes (Turjaman et al., 2008; Turjaman et al., 2008), and the use of surfactants to increase the binding capacity of peat soils (Utami, Maas, \& Radjagukguk, 2009). Further research that involve molecular identification of soil microbe is needed in order to see the information about the species and community dynamic along the revegetation process.

\section{CONCLUSION}

Post-fire peat soil were habitat for soil fungi and macrofauna. Based on the result, revegetation activities affect the soil fungi and macrofauna community. On the revegetated peat land, Soil chemical composition does not affect fungal soil and macrofauna community. The presence of fungi and macrofauna on postfire peat soil is affected by the understory cover. The denser understory cover, the abundance of soil fungi and macrofauna will increase.

\section{REFERENCES}

An, S., Cheng, Y., Huang, Y., \& Liu, D. (2013). Effects of Revegetation on soil microbial biomass, enzyme activities, and nutrient cycling on the loess plateau in China. Restoration Ecology, 
21(5), 600-607. doi://10.1111/j.1526100X.2012.00941.x.

An, S., Huang, Y., \& Zheng, F. (2009). Evaluation of soil microbial indices along a revegetation chronosequence in grassland soils on the Loess Plateau, Northwest China. Applied Soil Ecology, 41, 286-292. doi://10.1016/j. apsoil.2008.12.001.

Arnold, A. E. (2007). Understanding the diversity of foliar endophytic fungi: progress, challenges, and frontiers. Fungal Biology Reviews, 21(2-3), 51-66. doi://10.1016/j.fbr.2007.05.003.

Borror, D., Triplehorn, C., \& Johnson, N. (1992). Pengenalan pelajaran serangga (6 $6^{\text {th }}$ Ed.). Yogyakarta: Gadjah Mada University Press.

Bottinelli, N.,Jouquet, P., Capowiez, Y., Podwojewski, P., Grimaldi, M., \& Peng, X. (2015). Soil and tillage research why is the influence of soil macrofauna on soil structure only considered by soil ecologists ?. Soil « Tillage Research, 146, 118-124. doi://10.1016/j. still.2014.01.007.

Bridge, P., \& Spooner, B. (2001). Soil fungi: Diversity and detection. Plant and Soil, 232, 147-154.

Brussaard, L. (1997). Biodiversity and ecosystem functioning in soil. Ambio, 26(8), 563-570.

Carpenter, D., Hammond, P. M., Sherlock, E., Lidgett, A., Leigh, K., \& Eggleton, P. (2012). Biodiversity of soil macrofauna in the New Forest: A benchmark study across a national park landscape. Biodiversity and Conservation, 21(13), 3385-3410. doi://10.1007/s10531012-0369-0.

Coyle, D. R., Nagendra, U. J., Taylor, M. K., Campbell, J. H., Cunard, C. E., Joslin, A. H., ... Callaham, M. A. (2017). Soil biology and biochemistry soil fauna responses to natural disturbances, invasive species, and global climate change: Current state of the science and a call to action. Soil Biology and Biochemistry, 110, 116-133. doi://10.1016/j. soilbio.2017.03.008.

Dariah, A., S. Sutono, N.L. Nurida, W. Hartatik, E. P. (2015). Pembenah tanah untuk meningkatkan produktivitas lahan pertanian. Jurnal Sumberdaya Lahan, 9(2), 67-84.

Frouz, J., \& Jilkova, V. (2008). The effect of ants on soil properties and processes (Hymenoptera: Formicidae). Myrmecological News, 11(August), 191-199.
Gongalsky, K. B., Malmström, A., Zaitsev, A. S., Shakhab, S. V, Bengtsson, J., \& Persson, T. (2012). Do burned areas recover from inside? An experiment with soil fauna in a heterogeneous landscape. Applied Soil Ecology, 59, 73-86. doi://10.1016/j. apsoil.2012.03.017.

Gongalsky, K. B., \& Persson, T. (2013). Soil biology and biochemistry recovery of soil macrofauna after wild fires in boreal forests. Soil Biology and Biochemistry, 57, 182-191.

Gupta, I., Gorai, A., \& Sighn, R. (2007). Reclamation of coal-mine overburden dump through vegetation and association with macrofauna. Ecology Environment and Conservation, 13(2), 117-123.

Gusmailina. (2010). Pengaruh arang kompos bioaktif terhadap pertumbuhan anakan bulian (Eusyderoxylon zwageri) dan gaharu (Aquilaria malaccensis). Jurnal Penelitian Hasil Hutan, 28(2), 93-100.

Hakim, S. S., Yuwati, T. W., \& Nurulita, S. (2017). Isolation of peat swamp forest foliar endophyte fungi as biofertilizer. Journal of Wetland Environmental Management, 5(1), 10 17.

Halwany, W., Andriany, S., \& Manaon. (2014). Ekologi fauna tanah pada pola agroforestri berbasis jelutung di Kalimantan Tengah. In T. S. Hadi, Y. F. Arifin, \& H. Fauzi (Eds.), Ekspose Hasil Penelitian "30 tahun BPK Banjarbaru dalam Pembangunan Kehutanan" (pp. 155-162). Pusat Litbang Peningkatan Produktivitas Hutan, Banjarbaru.

Harun, M. K. (2011). Analisis pengembangan jelutung dengan sistem agroforestri untuk. memulibkan lahan gambut terdegradasi di Provinsi Kalimantan Tengah. Retrieved from https://repository.ipb.ac.id/ handle/123456789/53109 on 8 June 2019.

Istomo, \& Pradiastoro, A. (2011). Karakteristik tempat tumbuh pohon palahlar gunung (Dipterocarpus retusus Bl.) di kawasan hutan lindung gunung Cakrabuana, Sumedang, Jawa Barat. Jurnal Penelitian Hutan Dan Konservasi Alam, 8(1), 1-12.

Kirk, J. L., Beaudette, L. A., Hart, M., Moutoglis, P., Klironomos, J. N., Lee, H., \& Trevors, J. T. (2004). Methods of studying soil microbial diversity. Journal of Microbial Methods, 58, 169188. doi://10.1016/j.mimet.2004.04.006. 
Koster, K., Berninger, F., Jussi, H., Linden, A., Koster, E., Ilvesniemi, H., \& Pumpanen, J. (2015). The long-term impact of lowintensity surface fires on litter decomposition and enzyme activities in boreal coniferous forests. International Journal of Wildland Fire, 25(2), 213-223. doi://10.1071/WF14217.

Krebs, C. (1978). The experimental analysis of distribution and abundance. (2 ${ }^{\text {nd }}$ Eds.). Vancouver: University of British Columbia. Borror.

Kruger, D., Sharma, M., \& Ajit, V. (2009). Assessing the mycorrhizal diversity of soils and identification of fungus fruiting bodies and axenic cultures. In V. Ajit \& A. C. Kharkwal (Eds.), Symbiotic Fungi: Principles and Practices, 201303, 159-188. Springer-Verlag Berlin Heidelberg. doi://10.1007/978.

Lal, R. (1988). Effects of macrofauna on soil properties in tropical ecosystem. Agriculture, Ecosystem and Environment, 24, 101-116.

Maftuah, E., Alwi, M., \& Willis, M. (2005). Potensi makrofauna tanah sebagai bioindikator kualitas tanah gambut. Bioscientiae, 2(1), 1-14.

Malmstrom, A., Persson, T., Ahlstro, K., \& Malmstro, A. (2009). Dynamics of soil mesoand macrofauna during a 5 -year period after clear-cut burning in a boreal forest. Applied Soil Ecology, 43, 61-74. doi://10.1016/j. apsoil.2009.06.002.

Mandal, A., \& Sathyaseelan, N. (2012). Impact of climate change on soil biodiversity. A review. Agricultural Reviens, 33(4), 283-292.

Meador, A. S., Springer, J. D., Huffman, D. W., Bowker, M. A., \& Crouse, J. E. (2017). Soil functional responses to ecological restoration treatments in frequent-fire forests of the western United States: A systematic review. Restoration Ecology, 25(4497-508). doi://10.1111/rec.12535.

Neary, D. G., Klopatek, C. C., Debano, L. F., \& Ffolliott, P. F. (1999). Fire effects on belowground sustainability: A review and synthesis. Forest Ecology and Management, 122, 51-71.

Rolda, A. (2005). Use of microbiological indicators for evaluating success in soil restoration after revegetation of a mining area under subtropical conditions. Applied Soil Ecology, 30(1), 3-10. doi://10.1016/j. apsoil.2005.02.004.
Ruiz-jaen, M. C., \& Aide, T. M. (2005). Restoration success: How is it being measured? Restoration Ecology, 13(3), 569-577.

Santosa, P. B., \& Qirom, M. (2016). Memotret KHDTK Tumbang Nusa. Bekantan, 4(1), 7-10.

Shuhada, S. noor, Salim, S., Nobilly, F., Zubaid, A., \& Azhar, B. (2017). Logged peat swamp forest supports greater macrofungal biodiversity than large- scale oil palm plantations and smallholdings. Wiley Ecology and Evolution, 7, 7187-7200. doi://10.1002/ece3.3273.

Suhardjono, Y., Deharveng, L., \& Bedos, A. (2012). Biologi ekologi klasifikasi collembola (Ekorpegas). Bogor: Vegamedia.

Tawaraya, K., Takaya, Y., Turjaman, M., Tuah, S. J., Limin, S. H., Tamai, Y., ... Osaki, M. (2003). Arbuscular mycorrhizal colonization of tree species grown in peat swamp forests of Central Kalimantan, Indonesia. Forest Ecology and Management, 182(1), 381-386. doi://10.1016/S0378-1127(03)00086-0.

Thormann, M. N., \& Rice, a. V. (2007). Fungi from peatlands. Fungal Diversity, 24, 241-299. Retrieved from http://www.fungaldiversity. org/fdp/sfdp/24-10.pdf on 12 July 2019.

Thormann, M. N., Rice, A. V, \& Beilman, D. W. (2007). Yeasts in peatlands: A review of richness and roles in peat decomposition. Wetlands, 27(3), 761-773.

Too, C. C., Keller, A., Sickel, W., Lee, S. M., \& Yule, C. M. (2018). Microbial community structure in a Malaysian tropical peat swamp forest: The influence of tree species and depth. Frontiers in Microbiology, 9(December), 1-13. doi://10.3389/fmicb.2018.02859.

Trinder, C. J., Johnson, D., \& Artz, R. R. E. (2008). Interactions among fungal community structure, litter decomposition and depth of water table in a cutover peatland. FEMS Microbiology Ecology, 64(3), 433-448. doi://10.1111/j.1574-6941.2008.00487.x.

Turjaman, M., Saito, H., Erdy Santoso, Susanto, A., Gaman, S., Limin, S. H., ... Tawaraya, K. (2008). Effect of ectomycorrhizal fungi inoculated on Shorea balangeran under field conditions in peat-swamp forests Maman Turjaman. In J. H. Wösten, J. . Rieley, \& S. Page (Eds.), Restoration of Tropical Peatlands (pp. 154-159). Alterra, Wageningen 
University and Research Centre, and the EU INCO - RESTORPEAT Partnership.

Turjaman, M., Tamai, Y., Segah, H., Limin, S. H., Joo, Y. C., Osaki, M., \& Tawaraya, K. (2005). Inoculation with the ectomycorrhizal fungi Pisolithus arbizus and Scleroderma sp. improves early growth of Shorea pinanga nursery seedlings. New Forests, 30(1), 67-73. doi://10.1007/s11056-004-1954-1.

Turjaman, M., Tamai, Y., Sitepu, I. R., Santoso, E., Osaki, M., \& Tawaraya, K. (2008). Improvement of early growth of two tropical peat-swamp forest tree species Ploiarium alternifolium and Calophyllum hosei by two arbuscular mycorrhizal fungi under greenhouse conditions. New Forests, 36(1), 1-12. doi://10.1007/s11056-008-9084-9.

Utami, S.N.H., A. Maas, B. Radjagukguk, B. H. P. (2009). Restorasi gambut dengan tiga jenis surfaktan, dan pengaruhnya terhadap efisiensi penyimpanan kation dan kapasitas memegang air. Agritech, 29(1), 36-41.
Wang, C., Wang, G., Wang, Y., Hu, L., \& Luo, Y. (2015). Fire alters vegetation and soil microbial community in alpine meadow. Land Degradation and Development. 27, 13791390. doi://10.1002/ldr.2367.

Wawan Halwany. (2011). Keragaman makrofauna tanah sebagai indikator pengolahan lahan (Studi kasus pada lahan tanaman jelutung rawa (Dyera polyphylla)). In Prosiding Ekspose Hasil Penelitian: Dukungan BPK Banjarbaru dalam Pembangunan Kehutanan di Kalimantan (pp. 87-95). Pusat Litbang Peningkatan Produktivitas Hutan.

Yabuki, T., Duncan, I., \& Okuda, T. (2013). Full paper comparative study reveals unique features of the mycobiota in peat soils samples from Japan and Scotland. Mycoscience, 55(3), 168176. doi://10.1016/j.myc.2013.08.002. 